\title{
Perceptions of Consumer Impulse Buying Behavior in the Super Store: A Case Study of Some Selected Super Store in Bangladesh
}

\author{
Md. Alauddin ${ }^{1}$, Md. Musharof Hossain ${ }^{1}$, Md. Ibrahim ${ }^{1} \&$ Md. Ariful Hoque ${ }^{1}$ \\ ${ }^{1}$ Department of Business administration, International Islamic University Chittagong, Bangladesh \\ Correspondence: Md. Alauddin, Department of Business administration, International Islamic University \\ Chittagong, Bangladesh. E-mail: mdalauddin89@yahoo.com
}

$\begin{array}{lc}\text { Received: August 30, } 2014 & \text { Accepted: November 17, } 2014 \quad \text { Online Published: April 2, } 2015 \\ \text { doi:10.5539/ass.v11n9p68 } & \text { URL: http://dx.doi.org/10.5539/ass.v11n9p68 }\end{array}$

\begin{abstract}
Super stores are playing a key role in the field of shopping in Bangladesh. The popularity of super stores is increasing day by day in our country and consumers are becoming more habituated to buying from here. Today's consumers are also very much concern about food items. They want fresh, hygienic and healthy foods. So, super stores have become a great source for the consumers to get these items of foods. This paper is an attempt to investigate the factors that affect consumer impulse buying behavior at superstores in Bangladesh. Survey methodology was used to collect the data from 100 respondents by adopting simple random sampling technique. The study found that many factors were responsible for this changing buying behavior such as: in store atmosphere, point of purchase display, convenience, location, product characteristics, product quality, availability of branded items, store size, store image, variety seeking, discounts, stock outs, packaging, in store display etc. All of the characteristics are subject to consideration while making a purchase. Specifically planned purchase, generally planned purchase, substitute products all have an impact on impulse buying. The paper will be useful for marketing practitioners and researchers towards comprehensive understanding of the consumer's impulsiveness.
\end{abstract}

Keywords: super store, impulse buying behavior, planned purchase

\section{Introduction}

Super stores have become a new dimension of shopping in Bangladesh. It opens the modern path to shop in the most comfortable and relaxed shopping environment. It is a different type shop unlike departmental store or any type of grocery shop. It is much larger in size and in terms of quantity of products and much greater number of products is available. Impulse purchase or impulse buying means any purchase which a shopper makes, through it was not planned in advance. Impulse buying is defined here as a consumer's immediate response to external stimuli. It is not confined to a specific product category, but excludes the purchase of common household items (Madhavaram \& Laverie, 2004). Almost everyone makes impulse purchases at one time or another; it would seem that this is relatively simple phenomenon. A consumer sees some item, finds it appealing, and buys it, although he or she had not planned its purchase before entering the store. Actually unplanned purchase represents an important but troublesome area of consumer activity. Researchers and marketers are interested in the dynamics of impulse buying it accounts for a large proportion of purchasing behaviors. Studies indicate a great portion of the purchases in super shops are unplanned and that their number increases the amount of an individual's bill. As unplanned or impulse purchases occurs in a retail environment and are generally stimulated by in-store factors that marketers and retailers may control to varying degrees.

\section{Literature Review}

Research scholars have taken a very keen interest in impulse buying for the past sixty years (Clover, 1950; Stern, 1962; Rook, 1987; Peck \& Childers, 2006; Chang et al, 2011). Abratt and Goodey (1990) found that the examination of impulse buying in supermarkets could be of much interest to the manufacturers as well as retailers worldwide. Piron (1991) attempted to define the impulse buying by reviewing the past research works and found that the earlier studies revealed impulse buying to be very similar to unplanned purchasing (Clover 1950; West 1951), and forwarded his findings with managerial interests in mind. The managerial interest mainly refers to the focus on the product sales. Therefore in the earlier studies only the purchases were investigated and not the consumers traits. The researchers have suggested that impulse purchases can be further 
classified depending on the consumer's experiencing emotional and / or cognitive reactions.

Clover (1950) was first to study impulse buying mix and pointed out that some product categories are more sold on impulse. Stern (1962) defined impulse buying behavior by classifying as planned, unplanned, or impulse, also suggested that some product-related factors that might predict impulse buying. Kollat \& Willett (1967) found that the characteristics of consumers and their demographics influence the impulse purchasing. Rook \& Hock (1983) identify five crucial elements in impulse buying: a sudden and spontaneous desire to act, a state of psychological disequilibrium, the onset of psychological conflict and struggle, a reduction in cognitive evaluation and a lack of regard for the consequences of impulse buying. Rook \& Hoch (1985) argued that impulsive shoppers tend to enjoy shopping more and the impulses are result of consumer's sensation and perception driven by the environmental stimulus. Rook (1987) introduced the concept of consumer impulsion as a lifestyle trait, which can be linked to materialism, sensation seeking and recreational aspects of shopping. Piron (1991) defined impulse purchase based on four criteria-Impulse purchases are unplanned, decided "on the spot", stem from reaction to a stimulus and involve either a cognitive reaction, or an emotional reaction, or both. Rook \& Fisher (1995) introduced impulsiveness as a personality trait and defined as consumer's tendency to buy spontaneously, non-reflectively, immediately and kinetically. Beatty and Ferrell (1998) formulated the definition of impulse buying as a sudden and immediate purchase with no pre-shopping intentions either to buy the specific product category or to fulfill a specific buying task. Bayley \& Nancarrow (1998) suggested that impulse buying behavior is a complex buying process and the rapid decision process during shopping, prevents deliberate consideration of alternative information and choices. Youn \& Faber (2000) suggested that both positive and negative feeling states of consumer are potential motivators for impulse buying. Kacen \& Lee (2002) described that cultural forces could impact impulse purchasing of individuals. People having Independent self concept engage more in impulse buying. Crawford \& Melewar (2003) said that marketers should promote a good store layout to maximize the convenience of the consumer. A well trained salesperson can decrease frustration by guiding and aiding the consumer in the purchase process and activate impulse buying behavior (Crawford \& Melewar, 2003). Luo (2005) found that the presence of peers increases the urge to purchase, and that the presence of family members decreases it. Park, Kim \& Forney (2006) said that hedonic consumption has an indirect effect on fashion-oriented impulse buying. Fashion oriented people are pleasure and enjoyment seeking. Peck and Childers (2006) found that touch increases impulse purchasing as the distance between product and consumer decreases. They suggested that point-of-purchase signs, displays, and packaging encouraging product touch may increase impulse purchasing. Mattila \& Wirtz (2008) found that store environmental stimuli such as social factors (perceived employee friendliness) positively affect impulse buying behavior. Silvera, Lavack \& Kropp, (2008) studied the impact of emotions and inferred that impulse buying is influenced by the 'affect' or emotions of the consumer. Tirmizi, Rehman \& Saif (2009) clearly indicate that there exists a weak association between consumer lifestyle, fashion involvement and post-decision stage of consumer's purchasing behavior with the impulse buying behavior including the attitudinal as well as behavioral aspects of the consumers buying behavior. Pre-decision stage of consumer's purchasing behavior established strong association with the impulse buying behavior of the consumers. Dawson and Kim (2009) studied the affective-cognitive aspects and found significant relationship between a person's affective and cognitive state and their online impulse-buying behavior. Yu and Bastin (2010) said that hedonic shopping value of an individual lead to impulse purchases and are inextricably related to each other. Impulse buying varies across a broad range of product categories which include clothes, books and equipments for exercises (Yu \& Bastin, 2010). Sharma, Sivakumaran \& Marshall (2010) studied the variety seeking behavior of impulse buying. They found the variety seeking individuals are more prone to impulse purchases. Chang, Eckman \& Yan (2011) observed that the positive emotional responses of consumer to the retail environment result in impulsive purchases. Shen \& Khalifa (2012) observed that cognition of the consumer moderates the relationship among buying impulse and the actual impulsive behavior.

\section{Problem with Justification}

Now a day the way of people shopping are changing. They want much relaxed environment in a retail environment. Consumers want to buy more and more from Superstores. As they are ready to buy more frequently with specific plan and specific items often they visit super store. Frequency of visiting super shop increases the rate of unplanned that is impulse purchase. A lot of factors like specifically planned, generally planned, substitute products are involved to this nature of impulse buying which is a problem for consumer as well as shop owners.

There are some factors that influence consumer's unplanned nature of buying in the superstores. A lot of factors influence before made this type of buying such as in store characteristics, point-of-purchase display, locations, 
advertisements, quality of products, size of products, relaxation in the store, and above all the income level of consumers. Purchase made without much advance planning increases as the number of superstore has been establishing in the suitable locations that have significant impact to the impulse buying of consumers. A shopper may go to shopping with a mental note to buy one thing and buy another thing that may not be a necessity. This is an impact of all the factors mentioned above in impulse buying.

\section{Research Objectives}

\subsection{General Objective}

This research will focus on the consumer's different aspect of buying behavior of unplanned purchases of an impulse item.

\subsection{Specific Objectives}

The basic objectives of this research are:

- To identify the factors that influence consumers to make an impulse purchase.

- To find out the relationship among specifically planned generally planned, substitute and unplanned purchase.

- Brand consideration and substitute's effect to this type of buying.

a Determination of in-store characteristics that might affect impulse buying.

- Frequency of shopping trip in the super shop relation to impulse buying.

a Level of expenditure to this type of shop.

a Customer satisfaction level to this type of shopping.

\section{Research Methodology}

\subsection{Research Design}

This research is a descriptive one. Primary data has been used for data collection. A survey has been conducted as the method of collecting primary data. Data has been collected in many ways from consumers who have been visited the selected super store in the Dhaka city. Every individual respondent has been considered as potential respondent in the research. A close ended questionnaire has been developed and provided to the respondents for the convenience of the research. Personal interview has also been taken as the method of administering the questionnaire in the survey.

\subsection{Nature and Sources of Information}

Sources of information are primary in nature and data has been collected directly from the super shop those who came in the shop.

\subsection{Sampling Plan}

This research will be conducted through some convenient sample of consumer from the selected super shops. We selected Dhaka city for this paper due to capital city of Bangladesh. Almost 15 million inhabitants live in this city.

Table 1. Sampling for customer

\begin{tabular}{cc}
\hline Sampling Characteristics & Individual respondents \\
\hline Population & Consumers of Dhaka city \\
Sampling unit & Consumer who visit super shop \\
Element & Consumer who visited super shop \\
Extent & Dhaka city \\
Time & January-February`14' \\
\hline
\end{tabular}

Data has been collected through simple random sampling procedure.

Table 2. Sampling for providers

\begin{tabular}{cc}
\hline Sampling Characteristics & Individual Respondents \\
\hline Population & Shops in the Dhaka city \\
Sampling unit & Super shops in the Dhaka city \\
Element & Meena bazaar, Almas, PQS, \& Shop N Save \\
Extent & Dhaka city \\
Time & January-February'14' \\
\hline
\end{tabular}

Shops have been selected that met the criteria of a super shop. 


\subsection{Sample Size}

100 consumers have been selected randomly and interviewed twice before entering the store and at the time of leaving the store.

\subsection{Data Collection Methodology}

Primary sources of information have been used for data collection. Consumers who visited regularly and irregularly have been selected as respondents. A simple random sampling procedure has been applied for data collection. Before preparing the questionnaire a list of information has also been developed.

\subsection{Method of Data Analysis}

After collecting data from respondents, data analysis part has been started. First of all each questionnaire has been numbered from one to hundred. Then one by one has been taken and tabulated in a certain form so that this views a result.

In this analysis data has been analyzed by simple tabulation. Objective of the study has been considered as the guide line when data has been tabulated. The questions of the questionnaire that supports the particular objective has been separated first and tabulated thereby.

\section{Environmental and Situational Analysis and Its Results}

\subsection{Frequency of Visiting Super Shop}

Frequency of visiting to a super shop is number of times a consumer goes to shop in a definite period of time. First visit impression to a super store is influential for shopping tour to shops.

Table 3. Frequency of visiting super shop

\begin{tabular}{ccc}
\hline Factors & No. of respondents & No. of respondents in $\%$ \\
\hline Once in a week & 04 & $04 \%$ \\
Twice in a week & 0 & $0 \%$ \\
Once in a month & 11 & $11 \%$ \\
Twice in a month & 09 & $09 \%$ \\
No definite period of time & 76 & $76 \%$ \\
Total & 100 & \\
\hline
\end{tabular}

In this survey among one hundred respondents most of them have no definite time period to visit. $76 \%$ of the respondents fall into this category. Among the rest mostly visited once or twice in a month. It was also found that those who visit more frequently to buy more of impulse items than those of less frequent. More frequent visit increases the ranges of bills compare to less frequent visitors.

\subsection{Brand Choices in Specifically Planned Purchase}

People go to super store in order to buy specifically planned products. In this type of specific plan most of the respondents opine in favor of the specific branded items. Almost one -third of the respondents alter the brand though they come to buy specific items. Substitute products and brands often cause for changes.

Table 4. Brand choices in specifically planned purchase

\begin{tabular}{ccc}
\hline Factors & No. of respondents & No. of respondents in $\%$ \\
\hline Yes & 74 & $74 \%$ \\
No & 26 & $26 \%$ \\
\end{tabular}

In my study in case of specifically planned purchase most of the specific purchase is based on brand choice. It is about $74 \%$.

\subsection{Substitute Brand Consideration in Specifically Planned Purchase}

As it is mentioned, in case of specific plan most of the buyers bought specific branded products. But almost one-third is not much brand loyal to a specific item.

A number of factors influence a consumer to buy substitute brands or products. They are Saw merchandise, point of purchase of display, discount, variety seeking, stock outs, and recommendations of others. They bought substitute items by considering different in -store aspects. Among most of them are variety seekers, Pop display, discounts. Almost all of them consider more than one factor which is the opportunity for gaining competitive advantage and opportunity for capturing the market. 
Table 5. Substitute brand choices in specifically planned purchase

\begin{tabular}{ccc}
\hline Factors & No. of response & No. of respondents in $\%$ \\
\hline Saw merchandise & 02 & $0.97 \%$ \\
Point of purchase display & 59 & $28.78 \%$ \\
Discount & 58 & $28.29 \%$ \\
Variety Seeking & 60 & $29.27 \%$ \\
Stock out & 20 & $9.76 \%$ \\
Others recommendations & 06 & $2.93 \%$ \\
\hline
\end{tabular}

Table 3 shows that substitute products or brands considerations in specifically planned purchase. Almost $29 \%$ are responsible for variety seeking buying behavior and point of purchase display. Remaining factors in the sequence are discount $28.29 \%$, stock outs, others recommendations, and saw merchandise.

\subsection{In Store Characteristics Influence in Specifically Planned Purchase}

Most of the shoppers in my study hoped for a more relaxed environment and convenient and friendly environment in a super shop. They bother in the crowded and clumsy environment.

Table 6. In store characteristics influence in specifically planned purchase

\begin{tabular}{ccc}
\hline Factors & No. of respondents & No. of respondents in $\%$ \\
\hline Store location & 32 & $10.42 \%$ \\
Store image & 73 & $23.79 \%$ \\
Store size & 06 & $1.95 \%$ \\
Convenience & 88 & $28.66 \%$ \\
Store atmosphere & 85 & $27.69 \%$ \\
Others & 23 & $7.49 \%$ \\
\hline
\end{tabular}

In case of specifically planned purchase characteristics like store location, store image, store size, convenience, and lot other factors responsible for the recurrence of shopping store visit. Most of the respondents are influenced by more than two factors like convenience, store atmosphere, location etc.

Table shows that in-store characteristics influence in specifically planned purchase. A lot of factors causes for this type of purchase. Few of them are mostly responsible like convenience around $29 \%$, store atmosphere almost $28 \%$, store image nearly $24 \%$. Others factors like store location and other factors also responsible.

\subsection{Impulse Buying with Specifically Planned, Generally Planned and Substitute Buying}

Peoples visit to a super store for a specific plan to buy few specific items most of the time causes an item to buy that was not in his or her shopping list. This is an impulse buying.

Table 7. Impulse buying with specifically planned, generally planned and substitute buying

\begin{tabular}{ccc}
\hline Factors & No. of respondents & N. of respondents in $\%$ \\
\hline Yes & 97 & $97 \%$ \\
No & 03 & $03 \%$ \\
\end{tabular}

In this study, it shows that among the hundred consumers ninety seven of them bought impulse items in their visit to the super store.

\subsection{Shopping Trip Impact in the Super Store and Impulse Buying Patterns}

Number of times a shoppers visits to a super store increases the number of unplanned purchases.

Table 8. Shopping trip in the super store and impulse purchase

\begin{tabular}{ccc}
\hline Factors & No. of respondents & N. of respondents in $\%$ \\
\hline Very Often & 77 & $77 \%$ \\
Often & 23 & $23 \%$ \\
Not at all & 0 & $0 \%$ \\
\hline
\end{tabular}


From the survey, it is found that out of one hundreds respondents, $77 \%$ of them often buy one or more items that was not their planned, among them in this case $97 \%$ made an unplanned purchase. That may be an interesting as well as profitable segment for any providers.

\subsection{In-store Characteristics that Influence Impulse Purchase}

In-store characteristics like Point of purchase display, Price reduction and promotional deals, Outlet atmosphere, Stock outs, Packaging, Complements ,Others, are the relevant factors that might have an impact to make an unplanned purchase. In this study a number of factors were found that have huge influence on this type of purchase. Outlet atmosphere, pop display, price reduction and promotional deals are the most indicated character among them.

Table 9. In store characteristics influence in impulse purchase

\begin{tabular}{ccc}
\hline Factors & No. of respondents & No. of respondents (\%) \\
\hline Point of purchase display & 78 & $20.70 \%$ \\
Price reduction and promotional deals & 78 & $20.70 \%$ \\
Outlet atmosphere & 88 & $23.34 \%$ \\
Stock outs & 59 & $15.65 \%$ \\
Packaging & 18 & $4.77 \%$ \\
Complements & 20 & $5.30 \%$ \\
Others & 36 & $9.55 \%$ \\
\hline
\end{tabular}

From the table it is seen that the highlighting point in case of in-store, that is responsible for impulse purchase are outlet atmosphere, point of purchase display, price reduction and promotional deals.

Factors most responsible for impulse buying in in-store characteristics are outlet atmosphere $23.34 \%$, Point of purchase display almost $21 \%$, Price reduction and promotional deals around $21 \%$, stock outs approximately $16 \%$, and others are around $10 \%$.

\subsection{Relative Picture for Monthly Average Expenditure and Impulse Buying}

It is seen that there is a relation in the shopping trip and impulse buying. From this study we suppose to find out the relation between these two.

Table 10. Average expenditure and impulse buying

\begin{tabular}{cccc}
\hline No. of response & Avg. monthly expenditure & Exp. on impulse item & Percentage \\
\hline 1 & 2000 & 100 & $5 \%$ \\
1 & 2500 & 150 & $6 \%$ \\
13 & 3000 & 175 & $5.8 \%$ \\
10 & 3500 & 225 & $6.43 \%$ \\
10 & 4000 & 275 & $6.67 \%$ \\
10 & 4500 & 300 & $6.67 \%$ \\
9 & 5000 & 335 & $6.67 \%$ \\
12 & 5500 & 365 & $6.67 \%$ \\
12 & 6000 & 400 & $6.67 \%$ \\
8 & 6500 & 450 & $6.92 \%$ \\
7 & 7000 & 500 & $7.14 \%$ \\
4 & 7500 & 550 & $7.33 \%$ \\
3 & $8000+$ & 650 & $8.13 \%$ \\
\hline
\end{tabular}

Out of our randomly selected respondents, it shows that their average expenditure differ .Most of the respondent's expenditure ranges from 3000 to 5000. Large portion expenditure ranges from 5000 to 6000 . In our study it was found that there is a positive relation between expenditure and impulse buying. Those who expense more to the super shops the number of impulse that was unplanned items increased that results more expenses in this purchase trip.

\subsection{Customer Satisfaction Level in the Super Store}

Customer satisfaction is the perception about the store that they have made it visit in order to purchase products. In our queries they express their satisfaction level about the particular super shop they visited. 
Table 11. Customer satisfaction level in the super store

\begin{tabular}{ccc}
\hline Factors & No. of respondents & No. of respondents in $\%$ \\
\hline Fully satisfied & 05 & $05 \%$ \\
Somehow satisfied & 54 & $54 \%$ \\
Indifferent & 38 & $38 \%$ \\
Somehow dissatisfied & 03 & $03 \%$ \\
Totally dissatisfied & 0 & $0 \%$ \\
& 100 & \\
\hline
\end{tabular}

From the survey, it is found that customers are somehow satisfied on the total considerations. Fifty four percent of the respondents were among them. Thirty eight percent were indifferent towards the shop.

Figure is showing customer satisfaction level. In the study, it was found that $54 \%$ of the respondents are somehow satisfied and $38 \%$ are indifferent in their opinion. No one is totally dissatisfied.

\section{Policy Recommendations}

This research work has found out the impulse that is unplanned in case of buying behavior of consumers. We are also able to know about the super store, as well as consumers' expectations, perceptions about the store in which they made us visit. Following are some recommendations which may help them to enhance their performance and at the same time they can take prompt action against consumers' anomalies.

- Most of the impulse purchases are actually outcomes of some other characteristics like specifically planned, generally planned purchases. So they need to take initiatives to attract more customers which will increase the volume of impulse purchase

- In-store situations, this is largely responsible for impulse buying. Providers need to take every possible attempt to develop in-store requirements that the consumers expect from them.

- Store location is another highly noticeable subject to the customers. They always prefer to buy from nearer super stores. So location should be set considering the places of consumer's convenience so that they can easily buy from near about areas within their time limit.

- Consumer's awareness level is limited about the super store indeed. They are informed in most cases from personal sources. So intensive programs should be taken to inform a large number of potential customers.

- Car parking is a big issue to the customers who visit super shops. In most of the shops there is little parking space and that creates security problems. So increasing the parking space may reduce passerby harassment. If it is ensured properly, customers will be interested in frequent shopping.

- In most cases a large number of consumers visit super store with families and they are to concentrate on their children besides buying. So places like playing grounds can help parents to concentrate more on shopping with much relaxes as playing grounds for children may create more attraction for repeat purchases.

- More promotional activities like discounts, coupons, lottery, and incentives may increase impulse buying.

- Customer complaining system and prompt actions can help to increase good relation with them as well.

- Ease of shopping, improving the internal environment, quick response to instant queries may help to increase confidence of the consumers.

All of the above recommendations might help a lot to perform better in a retail environment.

\section{Conclusion}

In this modern period, lifestyle and livelihood of the people are changing as they are getting more facilities. They are reluctant to waste time and avoid harassment while they shop. The concept super store is the solution to these problems. People in large number from various social classes are also quite familiar with this modern shopping concept. It is increasing gradually but to be specific very steadily in the minds of consumers. Many factors are responsible for this changing buying behavior; these are - shopping ease, in store atmosphere, point of purchase display, convenience, location, product characteristics, product quality, availability of branded items, store size, store image, variety seeking, discounts, stock outs, others recommendation, complements, packaging, in store display etc. All of the characteristics are subject to consideration while making a purchase. Specifically planned purchase, generally planned purchase, substitute products all these factors have an impact on impulse buying. Frequency of purchase has an impact towards unplanned purchase that is every time a consumer visits a super store, each time he or she buys some products that was not his or consideration set. $97 \%$ of the consumers in the 
survey bought impulse products. As much as the expenditure increases the amount of impulse items rises. So there is a positive and very close relation between visiting a super store and the amount of impulse buying. This expenditure increases in proportion. For these above reasons marketers have the ample opportunity to gain a new segment of consumers.

\section{References}

Abratt, R., \& Goodey, S. D. (1990). Unplanned Buying and in store stimuli in Supermarkets. Managerial and Decision Economics, 11(2), 111-121. http://dx.doi.org/10.1002/mde.4090110204

Baylley, G., \& Nancarrow, C. (1998). Impulsive Purchasing: A qualative exploration of the Phenomenon. Qualative market Research, 1(2), 99-114. http://dx.doi.org/10.1108/13522759810214271

Beatty, S. E., \& Ferrel, M. E. (1998).Impulse Buying: Modeling its Precursors. Journal of Retailing, 74(2), 169-191. http://dx.doi.org/10.1016/S0022-4359(99)80092-X

Chang, H. J., Eckman, M., \& Yan, R. N. (2011). Application of the Stimulus-Organism-Response model to the retail environment: the role of hedonic motivation in impulse buying behavior. The International Review of Retail, Distribution and Consumer Research, 21(3), 233-249.

Clover, V. T. (1950). Relative importance of impulse-buying in retail stores. The Journal of Marketing, 15(1), 66-70.

Crawford, G., \& Melewar, T. C. (2003). The importance of impulse Purchasing Behaviour in international Airport Environment. Journal of Consumer behaviour, 3(1), 85-98. http://dx.doi.org/10.1002/cb.124

Dawson, S., \& Kim, M. (2009). External and internal trigger cues of impulse buying online. Direct Marketing: An International Journal, 3(1), 20-34.

Kacen, J. J., \& Lee, J. A. (2002). The Influence of Culture on Consumer Impulsive Buying Behavior. Journal of Consumer Psychology, 12(2), 163-176.

Kollat, D. T., \& Willett, R. P. (1967). Customer Impulse Purchasing Behavior. Journal of Marketing Research, $4(1), 21-31$.

Luo, X. (2005). How does shopping with others influence impulsive purchasing. Journal of Consumer Psychology, 15(4), 288-294

Madhavaram, S. R., \& Laverie, D. A. (2004). Exploring Impulse Purchasing on the internet. Advance in Consumer Research, 31, 59-66.

Mattila, A. S., \& Wirtz, J. (2008). The role of store environmental stimulation and social factors on impulse purchasing. Journal of Services Marketing, 22(7), 562-567

Park, E. J., Kim, E. Y., \& Forney, J. C. (2006). A structural model of fashion-oriented impulse buying behavior. Journal of Fashion Marketing and Management, 10(4), 433-446.

Peck, J., \& Chiders, T. L. (2006). If I Touch it I have to have it: Individual and environmental influences impulse purchasing. Journal of Business Research, 59(6), 765-769. http://dx.doi.org/10.1016/j.jbusres.2006.01.014

Piron, F. (1991). Defining Impulse Purchasing. Advances in Consumer Research, 18, 509-514.

Rook, D. W. (1987). The buying impulse. Journal of consumer research, 189-199. Retrieved from http://www.forbes.com/pictures/edgl45fdlj/no-1-dhaka-bangladesh

Rook, D. W., \& Fisher, R. J. (1995). Normative influences on impulsive buying behavior. The Journal of Consumer Research, 22(3), 305-313.

Rook, D., \& Hoch, S. (1985). Consuming impulses. Advances in Consumer Research, 7(1), 23-27.

Rook, H., \& Hock, A. (1983). Impulse Buying.Advance in consumer Research, 10, 562-567.

Sharma, P., Sivakumaran, B., \& Marshall, R. (2010). Impulse buying and Variety seeking: A trait-correlates perspective. Journal of Business Research, 63, 276-83.

Shen, K. N., \& Khalifa, M. (2012). System design effects on online impulse buying. Internet Research, 22(4), 396-425.

Silvera, D. H., Lavack, A. M., \& Kropp, F. (2008). Impulse buying: The role of affect, social influence and wellbeing. Journal of Consumer Marketing, 25(1), 23-33.

Stern, H. (1962). The Significance of Impulse Buying Today. Journal of Marketing, April, 59-62. 
Tirmizi, M. A., Rehman, K. U., \& Saif, M. I. (2009). An empirical study of consumer impulse buying behavior in local markets. European Journal of Scientific Research, 28(4), 522-532.

Youn, S., \& Faber, R. J. (2000). Impulse buying: its relation to personality traits and cues. Advances in consumer research, 27, 179-185.

Yu, C., \& Bastin, M. (2010). Hedonic shopping value and impulse buying behavior in transitional economies: A symbiosis in the Mainland China marketplace. Journal of Brand Management, 18(2), 105-114.

\section{Copyrights}

Copyright for this article is retained by the author(s), with first publication rights granted to the journal.

This is an open-access article distributed under the terms and conditions of the Creative Commons Attribution license (http://creativecommons.org/licenses/by/3.0/). 